\title{
Income Analysis, Added Value and Sustainability Strategy of Fish Processing Units (Case: "SMEs 88 Marijo”, in Pinrang Regency, South Sulawesi)
}

\section{Mutemainna Karim ${ }^{1}$, Darmawan Salman ${ }^{3}$, Jalil Genisa ${ }^{4}$, Rahmadanih ${ }^{3}$}

${ }^{1}$ Doctoral Program Students of Agricultural Science, Postgraduate School Hasanuddin University. Makassar, South Sulawesi, Indonesia

${ }^{2}$ Department of Fish Processing Technology Balikdiwa High School Technology Maritime of Makassar, South Sulawesi, Indonesia

${ }^{3}$ Department of Agribusiness, Faculty of Agriculture, Hasanuddin University, Makassar, South Sulawesi, Indonesia

${ }^{4}$ Department of Food Science Technology, Faculty of Agriculture, Hasanuddin University, Makassar, South Sulawesi, Indonesia

\begin{abstract}
This study aims to analyze the income, added value and business sustainability strategy of boneless milkfish processing. The method used in this research is a case study. The research location was chosen purposively at "SMEs 88 Marijo", Pinrang Regency, South Sulawesi Province. The consideration is that "SMEs 88 Marijo" has been operating for more than 10 years and is one of the milk processing businesses that have SNI certificates. Data were collected in December 2018 - April 2019 and analyzed descriptively qualitatively and quantitatively. The results showed that revenue from "SMEs 88 Marijo" in 2018 amounted to Rp 343,341,626. The highest income received came from boneless milkfish products amounting to Rp.299,537,126. The highest added value is obtained from "milkfish amplang" products, while the lowest value-added is boneless milkfish products. The ratio between total revenue and total costs $(\mathrm{R} / \mathrm{C}$ ratio) is 1.22 . $\mathrm{R} / \mathrm{C}>1$ means that the fish processing business is profitable, so it is feasible to be developed. The priority of sustainability strategy is: (1) Utilizing the potential of raw materials and waste through production diversification to create added value and increase revenue. (2) Increase competitiveness by applying GMP and SSOP to maintain the quality standard of SNI standard products. (3) Implement financial management effectively and manage business administration in a disciplined and accountable manner. (4) Building good relations and coordination with stakeholders; and (5) Disseminating information, promoting products, and providing the best service to its customers.
\end{abstract}

Keywords : SMEs, Added Value, Revenue, Strategy, Sustainability

\section{INTRODUCTION}

SMEs have developed into an important element in developing countries in the world because they absorb the largest workforce and contribute to large gross domestic income [1], [2], [3] [4] \& [5]. In Indonesia, SMEs even reach $99.99 \%$ of the total business units, which consist of micro-scale businesses that have a percentage of $98.85 \%$, small businesses $1.07 \%$, and medium scale businesses that have a percentage of $0.08 \%$. While the rest is $0.01 \%$ included in large-scale businesses [6]. SMEs in Indonesia plays a major role in driving economic growth because of their ability to create added value, but the majority of SMEs in these countries have poor performance [7]. Throughout the world and most of 
these businesses have experienced difficulties for years without significant growth [8].

The food processing industry has a strategic role in developing countries, in the context of globalization. The increasing importance of processed food exports when compared to primary commodities confirms this sector as a key component of export growth strategies for developing countries [9]. Fish processing is very important because fish is a commodity that is not durable or tends to rot [10]. For this reason, the existence of the fishing industry is very important. Processed fish can be a source of income where processed fish become semi-finished or finished products that are more durable and ready to be consumed by consumers and have economic value [11]. Industrialization of fisheries that cannot be separated from the marine and fisheries sector [12]. South Sulawesi Province is one of the centres for processing fishery products in Indonesia. Based on data from Fisheries Product Processing and Marketing Statistics in South Sulawesi Province, in 2014 the number of fish processing businesses was 2,067 with a workforce of 44,011 people, production volume was $1,414,111.9$ tons. But in 2016, the number decreased to 1,822 of fish processing businesses [13].

Since 2010 the government has designated milkfish as a commodity for the fishery industrialization program. This policy is directed to spur increased production, value-added and product competitiveness, so that Indonesia will be able to increase exports of milkfish, especially in the form of processed [14]. This policy is also very strong in supporting increased community fish consumption and food security programs. But until now, the availability of the milkfish commodity market is still dominated by the domestic market, where milkfish marketing has not fully utilized the opportunity to meet exports even though milkfish commodities are quite popular abroad.
Economic value added is very beneficial for SMEs because it is simple and can be understood by managers and is based on easily available information. SMEs need to use simple and holistic tools that can signal problems quickly and allow managers to identify the source of improvement. [15]. The valueadded analysis serves as an indicator of the success of the agribusiness sector. According to [16], the use of analyzing added value is to find out: 1) The amount of added value that occurs due to certain treatment given to agricultural commodities; 2) Distribution of benefits received by owners and workers; 3) The number of employment opportunities created by processing raw materials into finished products; 4) Opportunities and potential that can be obtained from a commodity system in a particular region because of applying certain technologies to one or several subsystems in the commodity system. The market opportunity for boneless milkfish products is huge because it is supported by an increase in demand to meet the needs of the community. Public awareness of the importance of consuming fish is also a driving force for increasing fish demand. The relatively large market potential attracts new producers in the boneless milkfish industry. The Maritime and Fisheries Office of Pinrang Regency also provides support in the training program, assistance in processing infrastructure facilities. and promotion of boneless milkfish products through exhibitions and offers to hotels, restaurants, hospitals, and the general public. To support the development of boneless milkfish processing units in South Sulawesi, the purpose of this study is to:

a. Analyzing the income and added value of boneless milkfish processing business in "SMEs 88 Marijo".

b. Knowing the sustainability strategy of boneless milkfish fish processing business in "SMEs 88 Marijo". 


\section{RESEARCH METHOD}

The method used in this research is a case study. Case studies are methods that aim to provide a detailed description of the background, nature, and character, which is typical of a case.

\subsection{Site Research}

This research was conducted at SMEs 88 Marijo, located in Manarang Village, Mattiro Bulu District, Pinrang Regency. The location of this research was chosen purposively. This research was conducted in December 2018 until March 2019.

\subsection{Research Respondents}

Respondents in this study were determined by the method of purposive sampling, namely the selection of key informants determined intentionally, which can provide information by the objectives of the study. The key informants were selected based on their duties and authority in the fish processing business of five, namely: Chairperson, Treasurer and Secretary of SMEs 88 Marijo, and Staff of the Marine and Fisheries Office of Pinrang Regency.

\subsection{Data Collection}

Data collection techniques in this study were direct observations to the research site, namely SMEs 88 Marijo. Data collection techniques had done convergent, in-depth observations, interviews with key informants, documentation, and triangulation [17].

\subsection{Data Analysis}

The data analysis method used in this research is descriptive qualitative and quantitative. Quantitative methods are used to find out income and added value. The qualitative descriptive method was used to analyze the sustainability strategy of the milkfish processing business in SMEs 88 Marijo. Analysis of the income and added value of milkfish processed is used to answer the first purpose of the study. Revenue analysis is a quantitative analysis that is used to see the benefits and efficiency of milkfish processing business production activities. The calculation of income in this study was done by calculating processed milkfish income for one year. Added value occurs because commodities undergo processes, transportation, and storage in one production process. Added value is influenced by technical and nontechnical factors. Information or output obtained from the value-added analysis results is the amount of added value, value-added ratio, margins and remuneration received by the owner of the factor of production [18].

\section{RESULTS AND DISCUSSION}

\subsection{The Dynamics of Developing SMEs 88 Marijo}

In 2008, Ms Mariyani Pandin began to pioneer and form SMEs of boneless milkfish processing called "KWT Menara Jaya", using as many as 8 workers. This business is located on Jalan Poros Pinrang-Parepare, Bulu Manarang Village, Mattiro Bulu District, Pinrang Regency, or about 208 km from Makassar City in South Sulawesi Province. Just like a new business was built, then this business in the initial stages only did processing that was still simple with an investment capital of Rp. 10 million, so the facilities they have are still lacking. The processing of boneless milkfish is done in an open space under the house, by flooring and using a bench. Technical knowledge of milkfish bone removal has not been obtained professionally. The initial stage of opening this business, only processing 50 -100 boneless milkfish per day. The boneless milkfish products were only sold to acquaintances and colleagues at the District Health Office of the Pinrang Regency. Mariyani Pandin was very enthusiastic about fulfilling all suggestions from various relevant agencies so that the change in the positive direction was gradually carried out. For its commitment to 
employee hygiene, handling, and storage of food, as well as pest control, sanitation of places and equipment, SMEs 88 Marijo obtained a One Star Charter for Food Safety in 2011.

In 2012, KWT Manara Jaya changed its name to SMEs 88 Marijo at the suggestion of a family member. SMEs 88 Marijo has a vision which is: Improving the living standards of the welfare of members in particular and society in general. As well as the mission, namely: (1). Creating jobs; (2). Increasing the economic growth and development of the surrounding community; and (3). Build partnerships and community empowerment efforts by prioritizing gender and poverty. SMEs 88 Marijo also received a Certificate of Feasibility Processing (SKP) from the Director-General of Fisheries Product Processing and Marketing of the Ministry of Maritime Affairs and Fisheries with Number P: 00001768 / PPHP / X / 2013. The boneless milkfish products of the SMEs 88 Marijo are declared to meet SNI requirements and obtain SNI certificates from the LSPro-HP BBP2HP (Fisheries Product Certification Institute, Center for Fisheries Product Processing and Marketing, Marine and Fisheries Ministry) dated June 16, 2014. Since then the SMEs 88 Marijo products have the right to put the SNI label on the product packaging. Since getting the SNI certificate, the production volume of SMEs 88 Marijo has increased. Along with the increase in production volume, In 2013, the number of employees increased to 16 people. Then, in 2014 the number of employees increased to 25 people. Then in 2017, the number of employees will increase again to 29 people.

\subsection{Analysis of Revenue and Added Value}

The processing of agricultural products will certainly produce value-added products, with increasing value of a product that will increase the income received by business actors [19]. The amount of income that will be obtained from an agricultural product processing activity depends on several factors that influence it, such as the level of production, intensity, and efficiency in the use of labour. The results of the analysis of income for processed boneless milkfish products in the 88 Marijo SMEs in 2018 can be seen in Table 1.

According to Table 1, in 2018 the 88 Marijo SMEs processed raw milkfish ingredients by $43,550 \mathrm{~kg}$ and produced $33,612 \mathrm{~kg}$ of boneless frozen milkfish products. Table 1 shows the production volume of boneless frozen milkfish as much as $33,612 \mathrm{~kg}$ with a product price of $\mathrm{Rp} .50,000$ / $\mathrm{kg}$, a revenue of Rp.1,680,594,500 is obtained. The total fixed cost to produce boneless frozen milkfish is Rp.64,472,374, which consists of: (1) Fixed labor costs of Rp.22,000,000; (2) Depreciation fee of Rp.39,631,464, -; and (3) Value Added Tax Charges of Rp.2,840,910. The total variable cost is Rp. 1,316,565,000. The profit earned is Rp.299,557,126. The ratio between revenue and costs for the SMEs 88 Marijo in 2018 is 1.22, meaning that every 1 rupiah issued will get an income of 1.22 rupiah. $\mathrm{R} / \mathrm{C}$ value Ratio greater than 1 indicates that SMEs 88 Marijo operates in a favourable condition.

Table 1. Analysis of income for boneless milkfish fish processing products for SMEs 88 Marijo in 2018

\begin{tabular}{|r|r|r|}
\hline No. & \multicolumn{1}{|c|}{ DESCRIPTION } & \multicolumn{1}{c|}{ TOTAL } \\
\hline 1 & Total Revenue & $\mathbf{1 , 6 8 0 , 5 9 4 , 5 0 0}$ \\
\hline 2 & Total Fixed Cost & $\mathbf{6 4 , 4 7 2 , 3 7 4}$ \\
\hline & a. Fixed Labor Costs & $22,000,000$ \\
\hline & b. Cost of depreciation & $39,631,464$ \\
\hline & c. Value Added Tax & $2,840,910$ \\
\hline 3 & Variabel Cost & $1,316,565,000$ \\
\hline & a. Milkfish raw material & $783,900,000$ \\
\hline & b. Labor & $435,500,000$ \\
\hline & c. Transportation & $14,050,000$ \\
\hline & d. Electricity & $23,005,000$ \\
\hline & e. Water & $5,600,000$ \\
\hline & f. Ice & $7,020,000$ \\
\hline & g. Consumption & $28,100,000$ \\
\hline & h. Packaging & $16,290,000$ \\
\hline & i. Unforeseen expenses & $3,100,000$ \\
\hline 4 & Total Cost & $1,381,037,374$ \\
\hline 5 & Total profit & $\mathbf{2 9 9 , 5 5 7 , 1 2 6}$ \\
\hline 6 & R/C Rasio & 1.22 \\
\hline
\end{tabular}

Source: Primary data processed, 2019 
Milkfish processing units such as SMEs 88 Marijo not only produce boneless milkfish products but also produce a variety of products that have high economic value, among others: shredded milkfish bones, milkfish meatballs, milkfish amplang, and fishbone sticks. An analysis of business income is conducted to determine the level of profitability of the milkfish processing business in 88 Marijo SMEs.
The amount of revenue is obtained by reducing total business revenues by total costs. After that, the level of profitability is seen from the calculation of the Revenue per Cost $(\mathrm{R} / \mathrm{C})$ ratio. $\mathrm{R} / \mathrm{C}$ ratio is the ratio between total revenues and total costs. The results of the income analysis for all milkfish processed products in 88 Marijo SMEs can be seen in Table 2.

Table 2. Analysis of Milkfish Processing Business Income of SMEs 88 Marijo in 2018.

\begin{tabular}{|c|c|c|c|c|c|c|c|}
\hline \multirow[b]{2}{*}{ NO } & \multirow[b]{2}{*}{ DESCRIPTION } & \multicolumn{5}{|c|}{ PRODUCT TYPE } & \multirow[b]{2}{*}{ TOTAL } \\
\hline & & Boneless Milkfish & $\begin{array}{l}\text { Shredded } \\
\text { Milkfish }\end{array}$ & $\begin{array}{l}\text { Milkfish } \\
\text { Amplang }\end{array}$ & $\begin{array}{c}\text { Milkfish } \\
\text { Meatballs }\end{array}$ & Milkfish Sticks & \\
\hline 1 & Raw material input (kg) & $43,550.00$ & 365.00 & 126.00 & 85.00 & 5.00 & $44,131.00$ \\
\hline 2 & Output (kg) & $33,612.00$ & 297.00 & 256.00 & 123.00 & 6.00 & $34,294.00$ \\
\hline 3 & Labor (HOK) & $7,587.00$ & 161.00 & 389.00 & 176.00 & 42.00 & $8,355.00$ \\
\hline 4 & Total Revenue (Rp) & $1,680,594,500.00$ & $38,023,000.00$ & $36,585,000.00$ & $8,568,000.00$ & $722,000.00$ & $1,764,492,500.00$ \\
\hline 5 & Raw material costs (Rp) & $783,900,000.00$ & - & $3,150,000.00$ & $2,120,000.00$ & - & $789,170,000.00$ \\
\hline 6 & Labor costs (Rp) & $457,500,000.00$ & $2,415,000.00$ & $5,835,000.00$ & $1,760,000.00$ & $210,000.00$ & $467,720,000.00$ \\
\hline 7 & Other input costs (Rp) & $139,637,374.00$ & $10,320,500.00$ & $12,226,000.00$ & $1,753,500.00$ & $323,500.00$ & $164,260,874.00$ \\
\hline 8 & Total Production Costs (Rp) & $1,381,037,374.00$ & $12,735,500.00$ & $21,211,000.00$ & $5,633,500.00$ & $533,500.00$ & $1,421,150,874.00$ \\
\hline 9 & Total Margin (Rp) & $299,557,126.00$ & $25,287,500.00$ & $15,374,000.00$ & $2,934,500.00$ & $188,500.00$ & $343,341,626.00$ \\
\hline 10 & Productivities (R/C Ratio) & 1.22 & 2.99 & 1.72 & 1.52 & 1.35 & 1.24 \\
\hline
\end{tabular}

Source: Primary data processed, 2019

Table 2 shows that in 2018, SMEs 88 Marijo also produced $296 \mathrm{~kg}$ of shredded fishbone products, 256 $\mathrm{kg}$ of milkfish amplang products, $123 \mathrm{~kg}$ of milkfish meatballs, and $6 \mathrm{~kg}$ of milkfish bones sticks. The business profitability (R / C-Ratio) of SMEs 88 Marijo if only producing boneless milkfish products is 1.22 but by diversifying production the profitability increases to 1.24. The profit also increased from Rp.299,557,126 to Rp.343,341,626 in 2018. The product that has the highest productivity is shredded milkfish, while boneless milkfish which is the main product has productivity Lowest. However, with a much higher level or volume of production, boneless milkfish products that provide the greatest profit value for SMEs 88 Marijo. Added value is the difference between commodities that are treated at a certain stage and the value of the sacrifices used during the process [18]. The amount of profit a product is influenced by the amount of added value [20]. The results of the value-added analysis of the milkfish processing business in the 88 Marijo SMEs can be seen in Table 3 .

In 2018, the average production of boneless milkfish in 88 Marijo SMEs was $2,801 \mathrm{~kg} /$ month by processing fresh milkfish of $3,629.17 \mathrm{~kg} / \mathrm{month}$. The conversion factor is 0.77 , obtained by comparing the average output with the average production input. This conversion factor shows that every $1 \mathrm{~kg}$ of processed fish will produce boneless milkfish weighing $0.77 \mathrm{~kg}$. The average labour used in processing boneless milkfish is $632 \mathrm{HOK}$, so the coefficient of labour used in processing $1 \mathrm{~kg}$ of boneless milkfish is 0.17 with a labour wage of $\mathrm{Rp} 60,300.51 / \mathrm{HOK}$. The labour coefficient is obtained from the comparison of the average labour used with the average input used in the processing process. Labour wages are obtained by adding up all labour costs and then divided by the total labour costs. 
Table 3. The added value of milkfish processing business for SMEs 88 Marijo in 2018

\begin{tabular}{|c|c|c|c|c|c|c|c|c|}
\hline \multirow{2}{*}{\multicolumn{2}{|c|}{ No }} & \multirow{2}{*}{\multicolumn{2}{|c|}{ Descriptions }} & \multicolumn{5}{|c|}{ VALUE ADDED PROCESSED MILKFISH PRODUCTS } \\
\hline & & & & \multirow[t]{2}{*}{$\begin{array}{l}\text { Boneless } \\
\text { Milkfish }\end{array}$} & \multirow[t]{2}{*}{$\begin{array}{c}\text { Shredded } \\
\text { Milkfish } \\
\end{array}$} & \multirow[t]{2}{*}{$\begin{array}{c}\text { Milkfish } \\
\text { Amplang } \\
\end{array}$} & \multirow[t]{2}{*}{$\begin{array}{c}\text { Milkfish } \\
\text { Meatballs } \\
\end{array}$} & \multirow[t]{2}{*}{$\begin{array}{c}\text { Milkfish } \\
\text { Sticks }\end{array}$} \\
\hline Out & tput & Input and Price & & & & & & \\
\hline 1 & & Output (kg/month) & a & $2,801.00$ & 24.75 & 21.33 & 10.25 & 0.50 \\
\hline 2 & & Raw Materisl Input (kg/month) & b & $3,629.17$ & 30.42 & 10.50 & 7.07 & 0.42 \\
\hline 3 & & Labor Input (HOK/month) & c & 632.00 & 13.42 & 32.42 & 14.67 & 3.50 \\
\hline 4 & & Convertion Factors & $d=a / b$ & 0.77 & 0.81 & 2.03 & 1.45 & 1.19 \\
\hline 5 & & Labor Coefficient & $e=c / b$ & 0.17 & 0.44 & 3.09 & 2.07 & 8.33 \\
\hline 6 & & Output/Product Price (Rp/kg) & $f$ & $50,000.00$ & 127,821 & $142,910.20$ & $69,658.54$ & $120,333.30$ \\
\hline 7 & & Average Labor Wage (Rp/HOK) & $\mathrm{g}$ & $60,300.51$ & $15,000.00$ & $15,000.00$ & $10,000.00$ & $5,000.00$ \\
\hline \multicolumn{9}{|c|}{ Revenue and Profit (Rp/kg) } \\
\hline 8 & & Price of Raw Materials (Rp/kg) & $\mathrm{h}$ & 18,000 & - & 25,000 & 25,000 & - \\
\hline 9 & & Other Input Costs (Rp / kg) & $\mathrm{i}$ & 2,975 & $34,749.16$ & $47,757.81$ & $14,256.10$ & $53,916.67$ \\
\hline 10 & & Output Value (Rp/kg) & $j=d x f$ & $38,590.09$ & $103,996.38$ & $290,311.86$ & $100,990.10$ & $143,253.93$ \\
\hline \multirow[t]{2}{*}{11} & a. & Value Added (Rp/kg) & $k=j-i-h$ & $17,614.79$ & $69,247.22$ & $217,554.05$ & $61,734.00$ & $89,337.26$ \\
\hline & b. & Value Added Ratio (\%) & $I=(k / j) \times 100 \%$ & 45.65 & 66.59 & 74.94 & 61.13 & 62.36 \\
\hline \multirow[t]{2}{*}{12} & a. & Employee Benefits (Rp / kg) & $m=e \times g$ & $10,501.00$ & $6,617.36$ & $46,314.29$ & $20,749.65$ & $41,666.67$ \\
\hline & b. & Labor Section (\%) & $\mathrm{n} \%=(\mathrm{m} / \mathrm{k}) \times 100 \%$ & 59.61 & 9.56 & 21.29 & 33.61 & 46.64 \\
\hline \multirow[t]{2}{*}{13} & a. & Benefits (Rp/kg) & $o=k-m$ & $7,113.79$ & $62,629.86$ & $171,239.77$ & $40,984.36$ & $47,670.59$ \\
\hline & b. & Benefits Ratio (Rp/kg) & $\mathrm{p} \%=(\mathrm{o} / \mathrm{k}) \times 100 \%$ & 40.39 & 90.44 & 78.71 & 66.39 & 53.36 \\
\hline \multicolumn{9}{|c|}{ Reply to the Owner of the Factors of Production } \\
\hline 14 & & Margin Benefits (Rp/kg) & $q=j-h$ & $20,590.09$ & $103,996.38$ & $265,311.86$ & $75,990.10$ & $143,253.93$ \\
\hline & a. & Benefits (\%) & $r=o / q \times 100 \%$ & 34.55 & 60.22 & 64.54 & 53.93 & 33.28 \\
\hline & b. & Labor (\%) & $\mathrm{s}=\mathrm{m} / \mathrm{q} \times 100 \%$ & 51.00 & 6.36 & 17.46 & 27.31 & 29.09 \\
\hline & c. & Other Inputs (Rp/kg) & $t=i / q \times 100 \%$ & 14.45 & 33.41 & 18.00 & 18.76 & 37.64 \\
\hline
\end{tabular}

Source: Primary data processed, 2019

The output value obtained by Marijo $88 \mathrm{UKM}$ is Rp. $38,590.09 / \mathrm{kg}$ boneless milkfish. This output value is obtained by multiplying the conversion factor by 0.77 with an output price of Rp. 50,000.-.kg. The added value obtained by SMEs 88 Marijo in producing boneless milkfish is Rp. 17,614.79/kg of output. The added value is obtained by subtracting the output value of Rp. 38,590.09 with raw material prices of Rp. $18,000.00$ and other input contributions of $\mathrm{Rp}$. 2,975.00. The value-added ratio of $45.65 \%$ of the value of output obtained by sharing the value-added with the value of output then multiplied by $100 \%$.

Labour income of Rp.10,501/kg boneless milkfish produced. This labour income is obtained by multiplying the labour coefficient of 0.17 with the labour wages of Rp. 60,300,51 / HOK. The value of the labour share of $59.61 \%$ is obtained by distributing labour income with added value then multiplied by $100 \%$. The profit gained by Marijo $88 \mathrm{UKM}$ is Rp.7,113.79/kg of boneless milkfish produced. This value is obtained from the reduction in value-added by Rp. $1,7,614.79 / \mathrm{kg}$ to the labour income of Rp.
$10,501 / \mathrm{kg}$. The level of profit of the entrepreneur is $40.39 \%$, which is obtained by distributing the profit of $\mathrm{Rp} .7,113.79 / \mathrm{kg}$ to the added value of Rp.1,7,614.79/kg then multiplied by $100 \%$.

The profit margin in processing boneless milkfish is Rp. 20,590.09/kg. Margin is obtained from the reduction in the output value of $\mathrm{Rp} .38,590.09 / \mathrm{kg}$ with raw material prices of Rp. 18,000/kg. The value of remuneration for entrepreneurs as owners of production factors is $34.55 \%$, obtained from the profit-sharing between the profit of Rp.7,113.79/kg with a profit margin of Rp.20,590.09/ kg multiplied by $100 \%$. Retribution for labour is $51 \%$, obtained from the profit-sharing between labour income of Rp.10,501/kg with a margin of Rp.20,590.09 / kg multiplied by $100 \%$. Repayment for other input contributions of $14.45 \%$, obtained from the sharing of other input contributions of Rp.2,975/kg with a margin of Rp. 20,590.09/kg multiplied by $100 \%$.

The amount of compensation obtained from the factors of production used in the 88 Marijo SMEs can 
be seen in Table 4. Overall the rewards for the factors of production used are for the business owner's portion of $49.30 \%$, Labor benefits of $26.24 \%$ and Rewards for other inputs $24.45 \%$.

Table 4. Rewards/share factors of production used in Marijo 88 SMEs

\begin{tabular}{|c|c|c|c|c|c|c|}
\hline \multirow[b]{2}{*}{$\begin{array}{l}\text { Reply to the Owner } \\
\text { of the Factors of Production }\end{array}$} & \multicolumn{5}{|c|}{ VALUE ADDED PROCESSED MILKFISH PRODUCTS } & \multirow[b]{2}{*}{ TOTAL } \\
\hline & Boneless Milkfish & $\begin{array}{l}\text { Shredded } \\
\text { Milkfish }\end{array}$ & $\begin{array}{l}\text { Milkfish } \\
\text { Amplang }\end{array}$ & $\begin{array}{l}\text { Milkfish } \\
\text { Meatballs }\end{array}$ & $\begin{array}{c}\text { Milkfish } \\
\text { Sticks }\end{array}$ & \\
\hline Margin Benefits (Rp/kg) & $20,590.09$ & $103,996.38$ & $265,311.86$ & $75,990.10$ & $143,253.93$ & $609,142.36$ \\
\hline Benefits (\%) & 34.55 & 60.22 & 64.54 & 53.93 & 33.28 & 49.30 \\
\hline Labor $(\%)$ & 51.00 & 6.36 & 17.46 & 27.31 & 29.09 & 26.24 \\
\hline Other Inputs $(\mathrm{Rp} / \mathrm{kg})$ & 14.45 & 33.41 & 18.00 & 18.76 & 37.64 & 24.45 \\
\hline
\end{tabular}

Source: Primary data processed, 2019

\subsection{Marijo Institutional Sustainability Strategy}

The SMEs 88 Marijo business sustainability strategy is (1) Applying the principle of clean production through innovation and developing product diversification to create added value and increase revenue. (2) Creating competitiveness by applying GMP and SSOP to maintain SNI standardized product quality degrees. (3) Applying financial management effectively and managing business administration in a disciplined and accountable manner. (4) Establish good relations and coordination with relevant stakeholders; and (5) Disseminating information, promoting products and providing excellent service to its customers.

\subsubsection{Utilize the potential of raw materials and waste through product diversification}

Cleaner production aims to prevent and minimize the formation of waste or environmental pollutants in all stages of production [21]. Conceptually the efforts made were 1E5R: Elimination; Reduction; Re-use; Recycle; and recovery. The main objective of this clean production is efficiency in the initial process until the end of production so that environmental sustainability is achieved [22]. The clean production concept that was earlier applied by SMEs of milkfish processing unit was to do Elimination, which is an effort to prevent the generation of the waste directly from its source, starting from raw materials, the production process until the product is ready to be marketed. The application of the principle of waste elimination is carried out starting from receiving raw materials, where SMEs 88 Marijo is very selective in choosing raw materials. Following the agreement with the supplier, SMEs 88 Marijo will return the raw material for milkfish which does not meet the requirements for processing.

The potential waste generated by SMEs 88 Marijo in 2018 is $9,938.11 \mathrm{~kg}$, which is $22.82 \%$ of the input volume of milkfish raw material used as many as 43,550 kg. SMEs 88 Marijo applies the principle of clean production by recycling waste through product diversification. Recycling is an effort to recycle waste to utilize waste by processing it back to the original process. Next is the recovery/reclaim effort, which is taking the material that still has a high economic value from the waste, then returned it to the production process.

The step of handling solid waste is done by reusing waste. Some types of waste that have been reused are damaged in processing. Solid waste in the form of milkfish is processed into fishbone stems. Fine bones 
and deep fins are processed into scarring. The remaining waste in the form of viscera or entrails of fish is processed by the labour as a family snack. Some are sold to interested consumers, the rest is used as animal feed and catfish feed. Waste in the form of fish scales was taken by the researchers but at present, there is no alternative use, so now only fish scales are wrapped and thrown into landfills. Creating good cooperation with employees in implementing clean production by setting scope and responsibilities. So that the balance of interests of each party is achieved. Optimal utilization of waste provides economic benefits and prevents environmental pollution.

Food industry liquid waste is one source of pollutants for the environment. These pollutants are generally in the form of suspended or dissolved organic matter in the form of carbohydrates, fats, proteins, and vitamins. Industrial wastewater is water that comes from a series of production processes that contain components and if discharged into the environment without proper management will be able to disrupt recipient water bodies [23]. Most of the food industry's liquid waste can be handled with biological systems. SMEs of boneless milkfish processing unit first screened the wastewater generated before being disposed of. Filtering liquid waste will remove most of the suspended solids, solutes and for filtering nutrients (nutrients) in the form of nitrogen and phosphorus. Filtering will reduce waste deposits at the source. UKM will dispose of liquid waste that has been free of solid material by first flowing it into catfish ponds, then into the drainage channel leading to rice fields. This liquid waste has the potential to become a natural organic fertilizer that fertilizes rice plants in the fields.

\subsubsection{Create competitiveness by applying GMP and SSOP}

The Fisheries Product Certification Institute team visited SMEs 88 Marijo at the end of 2013. The team evaluated the feasibility of the process of boneless milkfish production to obtain an SNI certificate. The requirements to get SNI were also prepared. The requirements cover the Standard Operating Procedure (SOP) for the production process. Processing facilities (factories) according to Good Manufacturing Practice (GMP) standards. Employees are equipped with knowledge and skills. The effort was not in vain, SMEs 88 Marijo succeeded in obtaining SNI Certificate for boneless milkfish products on June 16, 2014. 'SMEs 88 Marijo' is the only boneless milkfish processing unit that has obtained an SNI certificate in Indonesia. Since obtaining the SNI certificate, the production volume has increased. In 2012 the volume of the use of fresh milkfish raw material by $15,074.5 \mathrm{~kg}$ has doubled in 2014 , amounting to $31,600.0 \mathrm{~kg}$. Production volume in 2018 of 43,550 kg decreased from the achievement in 2017 which was $46,300 \mathrm{~kg}$. This is caused by the production holiday as an impact of an earthquake centred in Palu, Central Sulawesi in September 2018. The development of the volume of the use of fresh milkfish raw materials in SMEs 88 Marijo in 20122018 can be seen in Table 5 .

Table 5. The volume of raw milkfish raw material used in SMEs 88 Marijo in 2012-2018

\begin{tabular}{ccc}
\hline \hline Year & $\begin{array}{c}\text { Total Production } \\
(\mathbf{k g})\end{array}$ & $\begin{array}{c}\text { Production } \\
\text { Increase (\%) }\end{array}$ \\
\hline \hline 2012 & $15,074.50$ & - \\
2013 & $25,783.00$ & 71.04 \\
2014 & $31,600.00$ & 22.56 \\
2015 & $38,900.00$ & 23.10 \\
2016 & $41,287.00$ & 6.14 \\
2017 & $46,300.00$ & 12.14 \\
2018 & $43,550.00$ & $(5.94)$ \\
\hline \hline Average & $34,642.07$ & 21.51 \\
\hline \hline
\end{tabular}

Source: Primary data processed, 2019 
Based on Table 5, in 2017 the volume of input use of fresh milkfish raw material in SMEs 88 Marijo reached 46,300 kg. from 2012 to 2018, the use of fresh milkfish raw materials averaged 34,642.07 kg/year with an average increase of $21.51 \%$ per year. Thus the production volume of boneless milkfish has also increased significantly. The dynamics of the application of GMP and SSOP principles by SMEs 88 Marijo provides significant progress and results. SMEs 88 Marijo managed to get an SNI certification extension for boneless milkfish products which was valid until 2020. Some innovations such as milkfish fish processing which also managed to get SNI certificates. The processing of solid waste in the form of thorns becomes shredded milkfish which is in the process of obtaining SNI certificates. Patenting a particular product or technology, designing a new product, or developing a new distribution channel can only offer organizations temporary competitive advantage because sooner or later, competitors can imitate or improve upon innovation, which makes profits disappear. Success in discovering something new allows the organization to continue to gain a competitive advantage in the long run.

\section{IV.CONCLUSION}

The income obtained by SMEs 88 Marijo for all milkfish processed products in 2018 amounted to Rp $343,341,626$. The highest income received by SMEs 88 Marijo came from boneless milkfish products, amounting to Rp.299,557,126. The lowest income was obtained from milkfish sticks products amounting to Rp.188,500. The biggest added value was obtained from milkfish amplang products of Rp.217,554.05/kg, while the lowest value-added was boneless milkfish products of $\mathrm{Rp} .17,614.79 / \mathrm{kg} . \mathrm{R} / \mathrm{C}$ is the ratio between total revenue and total cost, $\mathrm{R} / \mathrm{C}>1$ means that the SMEs 88 Marijo milkfish fish processing business is profitable, has positive/beneficial added value and is worth the effort. The priority development strategies for the SMEs 88 Marijo are (1) Utilizing the potential of raw materials and processed waste to increase production to increase income. (2) Creating competitiveness by applying GMP and SSOP to maintain SNI standardized product quality degrees. (3) Applying financial management effectively and managing business administration in a disciplined and accountable manner. (4) Establish good relations and coordination with relevant stakeholders; and (5) Disseminating information, promoting products and providing excellent service to its customers.

\section{ACKNOWLEDGEMENT}

The author would like to thank all those who played a role in helping to realize this article. This research was jointly funded by the Ministry of Research and Technology Directorate General of Education in collaboration with the Graduate School of Hasanuddin University Makassar through the Doctoral Dissertation Grant in 2019.

\section{REFERENCES}

[1]. Indris, S. and I. Primiana. "Internal and External Environment Analysis On The Performance Of Small and Medium Industries (SMEs) In Indonesia". International Journal Of Scientific \& Technology Research, 4(4): 188196, 2015.

[2]. Prabawani, B. "Measuring SMEs' Sustainability: A Literature Review And Agenda For Research". International Journal of Management, and Sustainability, 2(12), 193207,

https://doi.org/10.18488/journal.11/2013.2.12/ 11.12.193.207

[3]. Kutlovci, E., V. Shala, and B. Troni. "Business Strategy, The Key Determinants of SME Groth in Kosovo". International Journal of Advance in Management and Economics 1(3): 42-46. 2012. 
[4]. Kim, Y. "SMEs in Africa: Challenges and the role of government for the future". Retrieved from

http://www.consultancyafrica.com/index.php? option=com_content\&vie, 2011.

[5]. Senjaya, K. dan R. H. Mustamu. "Pengelolaan dan Pengembangan Usaha pada Perusahaan Pengolahan Ikan Bandeng di Sidoarjo". Jurnal AGORA Volume. 1, No. 1. Universitas Kristen Petra, 2013.

[6]. Kementrian Koperasi dan UMKM. "Data Usaha Mikro Kecil Menengah UMKM dan Usaha Besar UB”, 2011. http://www.depkop.go.id

[7]. Kusi, A., CN Opata and TJ Narth. "Exploring the Factors That Hinder the Growth and Survival of Small Business in Ghana (A case Studt of Small Businesses within Kumasi Metropolitan Area”. American Journal of Industrial and Bussines Management, 5, 705-723, 2015. http://www.scirp.org/ journal/ajibm http://dx.doi.org/ 10.4236/ajibm.2015. 511070

[8]. Asa, A. R., \& Prasad, N. S. "Analysis on the Factors that Determine Sustainable Growth of Small Firms in Namibia”. International Journal of Management Science and Business Administration, 1(1), 5-11, 2014.

[9]. J. Wilkinson. "The Food Processing Industry, Globalization and Developing Countries". eJADE electronic Journal of Agricultural, and Development Economics. Vol. 1, No. 2, 2004, pp. 184-201, 2004.

[10]. Adawyah. "Pengolahan dan Pengawetan Ikan". Bumi Aksara. Jakarta, 2007.

[11]. Rahmantya, K.F., A.D. Asianto, D. Wibowo, T. Wahyuni, dan W.A. Somad. "Analisis Data Pokok Kementerian Kelautan dan Perikanan". Pusat Data Statistik dan Informasi. KKP, 2015.

[12]. Ministry of Maritime Affairs and Fisheries. "Maritime Affairs of Fisheries in Figures 2015. Center for Statistics and Information Data. Ministry of Maritime Affairs and Fisheries",
2016. (Online) (statistik.kkp.go.id/sidatikdev/Publikasi/src/kpda2015. Pdf. Accessed 16 December 2018)

[13]. Department of Maritime Affairs and Fisheries of South Sulawesi Province 2017 Processing and Marketing Statistics of Fisheries Products, 2016. Accessed www.dkpsulsel.org.

[14]. Kusnendar, E. "IPTEK Untuk Penyediaan Pangan dari Sektor Perikanan: Bandeng sebagai Komoditas Pangan Unggulan. Riset Untuk Keunggulan dan Daya Saing Bangsa. Bunga Rampai Pemikiran Dewan Riset Nasional. "Dewan Riset Nasional. Perpustakaan Nasional: Katalog Dalam Terbitan (KDT)”. ISBN : 978 979 - 9017 - 36- 9, 2013.

[15]. Bahri, M., J. St-Pierre, and O. Sakka. "Economic value added: A useful tool for SME performance management". International Journal of Productivity and Performance Management. Vol. 60 Iss 6 pp. 603 - 621, 2011. http://dx.doi.org/ 10.1108/ 17410401111150779

[16]. Hardjanto, W. "Sistem Komoditas Dalam Agribisnis. Sebuah Konsep Pengantar Diskusi LP3UK IPB”. Bogor, 1991.

[17]. J. W. Creswell, Research Design Qualitative and Quantitative Approaches. London: Sage Publications, 1994.

[18]. Hayami Y, Kawagoe T, Morooka Y, Siregar M. "Agricultural Marketing and Processing in Upland Java A Perspective From A Sunda Village. Bogor: CPGRT Centre, 1987.

[19]. Pertiwi, K. A., M. I. Affandi dan E. Kasymir. "Nilai Tambah, Pengendalian Persediaan Bahan Baku dan Pendapatan Usaha pada KUB Bina Sejahtera di Kelurahan Kangkung Kecamatan Bumi Waras Kota Bandar Lampung”. Jurnal Ilmu-ilmu Agribisnis, Volume 3 No. 1, Januari 2015: 26-31, 2015. http://jurnal.fp.unila.ac.id/

[20]. Mahardana, I.P.A., I.G.A.A. Ambarawati, dan I.N.G. Ustriyana. "Analisis Nilai Tambah Usaha Olahan Ikan (Kasus pada Kelompok Pengolah 
dan Pemasar Dwi Tunggal di Banjar Penganggahan, Desa Tengkudak, Kecamatan Penebel, Kabupaten Tabanan)". E-Jurnal Agribisnis dan Agrowisata ISSN: 2301-6523 Vol. 4, No. 2, 2015.

[21]. Sari DP. "Pengukuran Tingkat Eko-efisiensi Menggunakan Life Cycle Assessment Untuk Menciptakan Sustainable Production di Industri Kecil Menengah Batik”. Jurnal Teknik Industri. 14 (2): 137-144, 2012.

[22]. Ma'ruf, M., K. Sukarti., E. Purnamasari., E. Sulistianto. "Penerapan Produksi Bersih pada Industri Pengolahan Terasi Skala Rumah Tangga di Dusun Selangan Laut Pesisir Bontang (Application Cleaner Production Options on Fermented Shrimp Processing Industry in Household Scale in Selangan Laut, Bontang Waters)". Jurnal Ilmu Perikanan Tropis Vol. 18. No. 2, April 2013 - ISSN 1402-2006, 2013.

[23]. Moertinah, S. Kajian Proses Anaerobik sebagai Alternatif Pengolahan Air Limbah Industri Organik Tinggi J. Riset Teknologi Pencegahan Industri. 1 104-114, 2010.

\section{Cite this article as :}

Mutemainna Karim, Darmawan Salman, Jalil Genisa, Rahmadanih, "Income Analysis, Added Value and Sustainability Strategy of Fish Processing Units (Case: "SMEs 88 Marijo", in Pinrang Regency, South Sulawesi)", International Journal of Scientific Research in Science and Technology (IJSRST), Online ISSN : 2395-602X, Print ISSN : 2395-6011, Volume 6 Issue 6, pp. 221-231, November-December 2019. Available at doi : https://doi.org/10.32628/IJSRST196641 Journal URL : http://ijsrst.com/IJSRST196641 